\title{
PERANAN ORANG TUA DALAM MEMBINA KECERDASAN SPIRITUAL ANAK DALAM KELUARGA
}

\author{
H. Zulkifli Agus \\ Sekolah Tinggi Ilmu Tarbiyah Raudhatul Ulum Sakatiga \\ Email: zulkifli@stit-ru.ac.id
}

\begin{abstract}
Abstrak
Spiritual intelligence is very important in life, to achieve a calm and eternal life. But when viewed now many children have intellectual intelligence and emotional intelligence success with a myriad of achievements but he did not get satisfaction, happiness and peace of mind, because he does not have spiritual intelligence, and many parents who are less aware of the importance of spiritual intelligence of their children, and do not understand how to foster spiritual intelligence. The main problem of this research is how to foster spiritual intelligence of children in the family. The authors aim to raise this essay is to reveal ways or steps that can be done by parents in fostering spiritual intelligence, things that influence spiritual intelligence fostering and how the role of parents in fostering spiritual intelligence of children in the family. While the usefulness of this research is as a reference for parents, educators in trying to foster spiritual intelligence in children. Based on the results of research conducted by the author, it can be concluded that the essence of spiritual intelligence is the intelligence of the human soul derived from human nature itself which is closely related to religious and monotheistic aspects that can help a person build his true self into a true human being. The urgency of fostering spiritual intelligence in children, because with spiritual intelligence it makes children able to function intellectually and emotionally effectively and able to think more clearly, more positively to become a better person so that they can become true Muslim individuals. Factors that influence the formation of spiritual intelligence are innate (internal), and environmental (external) factors. The steps that must be considered by parents in fostering spiritual intelligence in children are introducing children to Allah, the Apostle, Islam, themselves, and the Qur'an. The role of parents in fostering spiritual intelligence in children is to educate, nurture, protect, help and develop children's spiritual intelligence to deliver it to the true source of spiritual intelligence (Allah SWT) through Islamic teachings contained in the Koran and the Hadith that has been exemplified by the Prophet.
\end{abstract}

Keywords: Intelligence, Spiritual, Family

\section{Pendahuluan}

\section{Deskripsi Kecerdasan Spiritual}

\section{Hakikat, Kecerdasan, spiritual.}

Kecerdasan spiritual terdapat perbedaan pendapat oleh beberapa ahli spiritual di antaranya yaitu sebagai berikut:

a. Zohar dan Marshal mendefinisikan“kecerdasan spiritual sebagai kecerdasan untuk menghadapi dan memecahkan persoalan makna dan nilai, yaitu kecerdasan untuk menempatkan perilaku dan hidup dalam konteks makna yang lebih luas dan kaya, kecerdasan untuk menilai bahwa tindakan atau jalan 


\section{Peranan Orang Tua dalam Membina Kecerdasan Spiritual Anak dalam Keluarga \\ H. Zulkifli Agus}

hidup seseorang lebih bermakna daripada yang lain". (Danah Zoha dan Ian Marsal, 2001:4)

b. Menurut Suki dimengutip pendapat Khalil A Khavari kecerdasan spiritual didefinisikan "sebagai fakultas dimensi non-material kita atau jiwa manusia. Ia menyebutnya sebagaii ntan yang belum terasah dan dimiliki oleh setiap insan. Kita harus mengenali seperti adanya, menggosoknya sehingga mengkilap dengan tekat yang besar, menggunakannya menuju kearifan, dan untuk mencapai kebahagiaan yang abadi".(Sukidi, 2004:77)

c. Kecerdasan spiritual menurut Stephen R. Covey adalah “...pusat paling mendasar di antara kecerdasan yang lain, karena dia menjadi sumber bimbingan bagi kecerdasan lainnya. Kecerdasan spiritual mewakili kerinduan akan makna dan hubungan dengan yang tak terbatas..." (Stephen R. Covey, 2005:8)

d. Menurut Toni Buzan mengutip pendapat Rodolf Otto, mendefinisikan "spiritual sebagai pengalaman yang suci. Pemaknaan ini kemudian diintroduksi oleh seluruh pemikir agama (spiritualis) dalam pemahaman makna keyakinan-keyakinan dalam konteks sosial mereka. Jadi tegasnya, spiritual diasumsikan bukan dalam pengertian diskursifnya, at home atau in side melainkan terefleksikan dalam perilaku sosialnya..." (Toni Buzan, 2001:57)

e. Ary Ginanjar Agustian mendefinisikan bahwa kecerdasan "spiritual adalah kemampuan untuk memberi makna ibadah pada setiap perilaku dan kegiatan melalui langkah-langkah dan pemikiran yang bersifat fitrah, menuju manusia seutuhnya (hanif), dan memiliki pola pemikiran tauhid (integralistik) serta berprinsip hanya karena Allah"..(Ary Ginanjar Agustian, 2001:57)

Dari berbagai pendapat di atas, penulis menyimpulkan bahwa Kecerdasan spiritual (SQ) adalah kecerdasan jiwa manusia yang berasal dari fitrah manusia itusendiri yang berkaitan erat dengan aspek religius dan ketauhidanyang dapat membantu seseorang membangun jati dirinya menjadi pribadi insan sejati, kreatif ketika dia dihadapkan pada masalah kehidupan, dan mampu menyelesaikannya dengan baik dengan memperoleh kepuasan, ketenangan dan kedamaian hati, serta mampu memaknai setiap kegiatannya sebagai ibadah dalam pengabdian kepada Allah SWT. Dan ini merupakan kecerdasan terpenting dalam menapaki kehidupan di dunia inidemi mencapai misi hidup kesuksesan di dunia dan akhirat.

\section{Urgensi Pembinaan Kecerdasan Spiritual Pada Anak}

Secara garis besar ada dua kebutuhan anak yakni kebutuhan jasmani dan kebutuhan rohani (spiritual)...".(Suharsono, 200:118). orang tua (ayah dan ibu) hendaknya memperhatikan keseimbangan antara kebutuhan jasmani dan rohani anak. Oleh sebab itu orang tua harus memberikan makanan yang halal dan bergizi kepada anak balita agar otaknya tumbuh dengan sempurna, di samping memenuhi kebutuhan rohani dengan membina kecerdasan spiritualnya.

Kecerdasan spiritual sangat menentukan perkembangan kepribadian anak. Namun dewasa ini tidak sedikit para orang tua yang kurang memperhatikan 
Volume 4 Nomor 2 Edisi Desember 2019

P-ISSN : 2541-3686

keseimbangan antara kebutuhan jasmani dan kebutuhan akan spiritual anak. Orang tua cendrung lebih memperhatikan kebutuhan jasmani anak dari pada kebutuhan dalam mencerdaskan spiritualnya. Hal ini dapat dilihat dari kenyataan bahwa semakin banyaknya anak-anak yang sehat dan cerdas tetapi spiritualnya belum tentu cerdas. Sebagai contoh Irianti Erningpraja seorang presenter dan pencipta lagu. Ia belum merasakan kepuasan, Irianti memang bangga akan semua prestasi yang diraihnya, namun dia masih merasa kosong seolah-olah tidak ada sesuatu yang besar telah terjadi, prestasinya juga tercetak di dunia olah raga. Berulang kali dia memperoleh mendali di tingkat Internasional, di tingkat SEA Games, ditingkat ASIA Games. Irianti juga pernah menyabet mendali emas untuk renang tahun 1977, namun segudang prestasi ini hanya berlalu begitu saja di hatinya. Di bidang akademis, Irianti juga pernah mendapatkan beasiswa dan dia juga tercatat sebagai alumni Jurusan Statistik Institut Pertanian Bogor. Selain itu ia juga merasa dirinya cepat sekali marah, ada orang salah sedikit kepadanya dia pasti marah, bahkan Irianti sempat mengubah namanya karena kesal banyak orang salah menulis namanya. Kegelisahan Irianti mulai reda setelah ia membaca buku-buku tentang pengembangan diri. Terutama masalah kecerdasan spiritual. Dia mulai menyadari walaupun dia punya segudang kecerdasan, tetapi jika tidak dibarengi dengan kecerdasan spiritual, jiwanya tidak akan merasakan kebahagiaan. Irianti merupakan salah seorang contoh dari ribuan, bahkan jutaan anak yang tidak merasakan kebahagiaan atas apa yang telah mereka raih.( http://www.scribd.com/doc/6719346/Skripsi-Membina-Kecerdasan-Spritual-Anak)

Di sinilah barang kali letak kesenjangan perhatian sebagai orang tua dalam kaitannya dengan pendidikan anak. Karena itulah setiap orang tua harus menyadari dan memperhatikan keseimbangan antara kebutuhan jasmani dan rohani (spiritual) anaknya.

Berdasarkan contoh diatas menunjukkan betapa pentingnya membina kecerdasan spiritual anak, khususnya dalam lingkungan keluarga. Menurut Hasan Langgulung orang tua supaya "lebih memperhatikan anak-anaknya, tidak hanya dari segi IQ dan EQnya saja, tetapi SQ yang lebih diutamakan ditanamkan kepada anak-anaknya. Orang tua tidak lagi mengabaikan kecerdasan spiritual anaknya. Pendidikan agama dan Spiritual termasuk bidang-bidang pendidikan yang mendapat perhatian penuh oleh keluarga (orang tua) terhadap anakanaknya..."(Hasan Langgulung, 1995:372).

Oleh karena itu, sebaiknya pada saat anak lahir ke dunia, orang tua hendaknya lebih memperhatikan spiritual anaknya dengan mengadzankan di telinga kanan dan mengiqamahkan di telinga kiri. serta memberikan nama yang baik, mengaqiqahkan, dan amalan shaleh lainnya.

Sebagai orang tua, tidak hanya berkewajiban memenuhi kebutuhan jasmaniah anak semata tetapi juga kebutuhan spiritual anak dalam mencapai kebahagiaan dunia dan akhirat. Dengan cara membiasakan anak sejak dini dengan hal-hal yang sesuai dengan nilai-nilai kesusilaan dan agama diharapkan akan terbentuk akhlak 


\section{Peranan Orang Tua dalam Membina Kecerdasan Spiritual Anak dalam Keluarga H. Zulkifli Agus}

dan pribadi yang baik pula dimasa-masa selanjutnya, sehingga pada gilirannya anak dapat membedakan mana yang baik dan terbaik dan mana yang buruk dan terburuk, mana yang benar dan mana yang salah dalam kehidupan sehari-hari.

Dari berbagai pendapat di atas, penulis menyimpulkan bahwa pentingnya membina kecerdasan spiritual pada anak, karena dengan kecerdasan spiritual itu membuat anakmampu memfungsikan IQ dan EQ secara efektif dan mampu berfikir lebih jernih, lebih positif untuk menjadi orang yang lebih baik sehingga mampu menjadi pribadi muslim sejati, mampu bangkit dari kegagalan, tidak terpuruk dalam penderitaan dan mampu menjadi motivator bagi diri sendiri dan orang lain sehingga mampu menjadi orang yang bijaksana dalam menjalani dan menyikapi kehidupan untuk meraih kebahagian yang hakiki, mampu membuat hidupnya lebih bermaknadengan menjalin hubungan baik sesama manusia (hablum minannas) dan hubungan baik dengan Allah (hablum minallah) dan selalu merasa diawasi oleh Allah (muraqabatullah).

\section{Faktor-Faktor yang Mempengaruhi Pembinaan Kecerdasan Spiritual}

Ada beberapa faktor yang mempengaruhi kecerdasan spiritual seseorang. Menurut Syamsu Yusuf "faktor pembawaan (internal) dan lingkungan (ekstrnal)"(Syamsu Yusuf LN, 2001:136). Adapaun penjelasannya sebagai berikut:

a. Faktor Pembawaan (internal)

Secara hakiki perbedaan manusia dengan binatang adalah manusia mempunyai fitrah beragama. Oleh sebab itu manusia disebut juga dengan homo religius. Fitrah beragama ini tidak memilih kapan manusia tersebut itu berada dan dilahirkan. Dari zaman yang masih primitif sampai modern, bahkan sejak Nabi Adam sampai akhir jaman, maupun setiap anak yang lahir dari rahim orangtua yang baik ataupun jahat, bahwasanya secara kodrati setiap manusia memiliki kepercayaan terhadap sesuatu yang berada di luar kekuasaannya yang memiliki kekuatan untuk mengatur kehidupan alam semesta.

Dalam masyarakat primitif sering dijumpai melalui bukti-bukti peninggalan prasejarah. Adanya kepercayaan terhadap roh-roh gaibyang dapat memberikan kebaikan atau kejahatan. Semua hal tersebut diperlihatkan melalui pemberian sajisajian yang dibuat untuk mengusir ataupun meminta tolong kepada roh-roh yang mereka percayai. Selain itu benda-benda yang dianggap keramat, seperti keris, atau batu juga seringkali mereka percayai sebagai benda yang memiliki kekuatankekuatan yang dapat mendatangkan kebaikan bagi dirinya sendiri. Tidak heran jika mereka mengeramatkannya. Bahkan, dikalangan masyarakat modern pun masih ada yang percaya terhadap hal-hal yang bersifat takhayul tersebut.

Melihat kenyataan di atas maka tidak bisa dipungkiri bahwa setiap manusia yang lahir telah memiliki kepercayaan terhadap suatu zat yang mempunyai kekuatan untuk mendatangkan kebaikan ataupun kemudhoratan (mencelakakan). Namun dalam perkembangannya, fitrah beragama ini ada yang berjalan secara alamiah, dan ada juga yang mendapat bimbingan dari para rasul Allah SWT, sehingga fitrahnya berkembang sesuai dengan kehendak Allah SWT. 
Volume 4 Nomor 2 Edisi Desember 2019

P-ISSN : 2541-3686

b. Faktor Lingkungan (eksternal)

Fitrah beragama merupakan salah satu potensi yang memiliki kecenderungan untuk berkembang ke arah yang lebih baik lagi. Namun potensi tersebut tidak akan berkembang manakala tidak ada faktor luar (eksternal) yang turut serta mewarnai pertumbuhan dan perkembangan setiap individu. Jika orang tua menginginkan potensi beragama setiap anak berkembang ke arah yang lebih baik, tentu orang tua harus dapat menkondisikan situasi dan lingkungan yang ada disekitar mengarah kepada hal tersebut untuk mencapai tujuan yang diinginkan.

Disini lingkungan yang dimaksud menurut Syamsu Yusuf LN adalah lingkungan“...keluarga, sekolah, dan masyarakat. Adanya keserasian antara keluarga, sekolah, dan masyarakat akan dapat memberikan dampak positif bagi anak, termasuk dalam pembentukan jiwa keagamaan dalam diri anak"(Ibid: 139). Adapun penjelasannya dari masing-masing lingkungan adalah sebagai berikut:

1) Lingkungan keluarga

Keluarga merupakan lingkungan yang pertama dan utama bagi setiap anak. Tentunya dalam hal ini orangtua menjadi orang yang paling bertanggungjawabdalam menumbuhkembangkan kecerdasan beragama pada anak. Para orangtua dibebankan tanggungjawab untuk membimbing potensi keagamaan anak sehingga diharapkan akan terbentuk kesadaran beragama (religious consciousness) dan pengalaman agama (religious experience) dalam diri anak-anak secara nyata dan benar. Anak-anak diberi bimbingan sehingga mereka tahu kepada siapa mereka harus tunduk dan bagaimana tatacara sebagai bentuk pernyataan dan sikap tunduk tersebut.

Tentunya pembentukan jiwa keagamaan ini haruslah dimulai sejak anak lahir. Setiap orang tua harus mengumandangkan azan ditelinga kanan dan iqamah di telinga kiri. Hal tersebut dimaksudkan agar suara yang pertama kali didengar oleh anak adalah kalimat-kalimat seruan kepada Allah sebagai tanda pengajaran kepada anak yang baru memasuki dunia baru. Lalu ada usia ketujuh hari sebaiknya anak di aqiqahkan dan diberi nama yang baik sebagai salah satu doa agar menjadi anak yang sholeh dan sholehah.

Kemudian Islampun mengajarkan kepada setiap orang tua untuk selalu memberikan anak makanan dan minuman yang halal dan baik yaitu makanan dan minuman yang tidak diharamkan oleh agama.

Pada periode selanjutnya anak harus diperlakukan dengan kasih sayang, dan orang tua harus dapat memberikan keteladanan melalui perkataan, sikap dan perbuatan yang direalisasikan dalam kehidupan sehari-hari secara konsisten.

2) Lingkungan Sekolah

Lingkungan sekolah merupakan lingkungan kedua bagi anak setelah keluarga. Karena hampir setengah hari anak menghabiskan waktunya bersama teman dan gurunya di sekolah. Tentunya segala sesuatu yang ada di sekolah akan menjadi model bagi anak untuk ditiru. Pengaruh sekolah terhadap perkembangan kepribadian anak sangat besar, karena sekolah merupakan subtitusi dari keluarga 


\section{Peranan Orang Tua dalam Membina Kecerdasan Spiritual Anak dalam Keluarga H. Zulkifli Agus}

dan guru-guru subtitusi dari orang tua.( http://www.sarjanaku.com/2013/04/pengertian-lingkungan-sekolah-faktor.)

Hal ini menggambarkan bahwa guru merupakan orang tua kedua bagi anakanak. Peran guru di sekolah memberikan kontribusi yang sangat besar bagi seluruh perkembangan anak, baik kognitif, sosial, emosi maupun afektif. Sayangnya masih banyak sekolah yang lebih menitikberatkan perkembangan anak secara akademik dengan mengukur kecerdasan setiap anak melalui deretan angka sebagai salah satu ukuran perbandingan antara anak yang satu dengan yang lainnya.

Tentunya hal tersebut harus dijadikan bahan pemikiran bagi seluruh guru sebagai penanggungjawab pendidikan bagi anak untuk tetap menggali seluruh potensi dan kecerdasan anak sesuai dengan tahapan perkembangannya. Karena sekolah adalah lembaga pendidikan formal yang mempunyai program sistemik dalam melaksanakan pengajaran, bimbingan dan latihan kepada anak agar mereka berkembang sesuai dengan potensinya.

Dalam kaitan mengembangkan fitrah keagamaan dalam diri anak, maka guru wajib memberikan keteladanan dan perkataan, sikap maupun perbuatan yang baik serta cara berpakaian yang sesuai dengan ajaran agama Islam dalam kehidupan sehari-hari. Semua itu akan lebih efektif jika semua guru dan staf di sekolah dapat merefleksikanya melalui pembiasaan yang dimulai dari diri sendiri. Selain itu diperlukan juga guru agama yang memiliki kepribadian yang akhlak mulia, menguasai disiplin ilmu agama Islam, dan memahami ilmu-ilmu yang lain yang menunjang kemampuannya dalam mengelola proses belajar mengajar. Namun bukan berarti pengembangan kecerdasan beragama hanyalah menjadi tanggungjawab guru agama saja. Melainkan juga menjadi tanggung jawab guru bidang studi lain dengan cara tetap menyisipkan nilai-nilai agama dalam seluruh proses belajar mengajar setiap hari.

3) Lingkungan Masyarakat.

Selain faktor keluarga dan sekolah, lingkungan masyarakat juga turut mempengaruhi perkembangan kecerdasan beragama pada anak. Lingkunan masyarakat yang dimaksud meliputi lingkungan rumah sekitar anak sebagai tempat bermain, televisi, serta mediacetak seperti buku cerita maupun komik yang paling banyak digemari oleh anak-anakusia dini. "Lingkungan masyarakat adalah situasi atau kondisi interaksi sosial dan sosiokultural yang secara potensial berpengaruh terhadap perkembangan fitrah beragama atau kesadaran beragama individu".(Syamsu Yusuf LN: 141). Dalam masyarakat akan terbentuk suatu perilaku yang dominan pada setiap individu karena adanya interaksi sosial yang terjadi antara teman sebaya maupun dengan anggota masyarakat lainnya. Pada diri anak akan muncul perilaku baik ataupun tidak baik tergantung seberapa besar lingkungan sekitarnya mempengaruhi dalam pergaulan sehari-hari. Karena pada dasarnya anak cepat sekaliterpengaruh oleh hal-hal yang ia lihat, dengar dan rasakan.

Aturan-aturan 'gang' (kelompok bermain) memberikan pengaruh kepada pandangan moral dan tingkah laku para anggotanya. Disini dapat dikemukankan 
Volume 4 Nomor 2 Edisi Desember 2019

P-ISSN : 2541-3686

bahwa kualitas perkembangan kesadaran beragama bagi anak sangat bergantung pada kualitas perilaku atau pribadi orang dewasa atau warga masyarakat. Jika anak sering bergaul dengan lingkungan yang kurang baik, maka bukan tidak mungkin anak akan berperilaku sama dengan apa yang ia lihat dan dengar dalam kehidupan sehari-harinya.(http://buleksiet.blogspot.co.id/2013/06/keterkaitan-kecerdasanemosi-dan).

Selain manusia sebagai faktor yang mempengaruhi perkembangan beragama anak, media cetak dan televisi juga turut serta memberikan andil besar dalam mewarnai pertumbuhan anak dalam lingkungannya.

\section{Langkah-langkah Pembinaan Kecerdasan Spiritual}

Langkah-langkah pembinaan kecerdasan spiritual adalah metode atau cara yang ditempuh "...dalam rangka mengantarkan manusia menjadi seseorang yang kaya spiritual dan intelektual, sehingga dia dapat meningkatkan kualitas hidup di segala aspek dan menjalani kehidupan dengan cita-cita dan tujuan yang pasti".(Ahmad Syafii Maarif:6). Untuk itu dalam pembinaan kecerdasan spiritual langkah yang harus dilakukan oleh orang tua adalah memahamkan anak tentang Islam secara

(kaffah) sempurna.(https://zuhdifirdaus.wordpress.com/2008/08/28/etika-pendidikanpembentukan-kecerdasan- spiritual.)

Adapun langkah-langkahnya sebagai berikut:

a. Mengenalkan anak kepada Allah (ma'rifatullah), yaitu dengan mengenalkan nama-nama dan sifat-sifat Allah serta ciptaan-Nya. Jasiman mengutip pendapat Imam Ibnu Qoyyim mengatakan bahwa ma'rifatullah adalah "pengenalan yang dapat menimbulkan perasaan malu, kecintaan, keterikatan hati, kerinduan, taubat, kedekatan, dan hanya berharap kepada-Nya".(Jasmin, 2009:49). Mengenal Allah menjadi sangat urgenbagi seorang hamba karena yang akan ia kenali adalah Pencipta semesta alam yang telah menguasai manusia dan menyiapkan segala untuknya kebutuhan di langit dan di bumi, menciptakan malaikat, hewan, tumbuhan, dan makhluk lainnya yang kesemuanya ditundukkan untuk manusia. Cara mengenal Allah melalui ayatayat-Nya, yaituayat-ayat qouliyah(Al-Qur'an)dan ayat-ayat kauniyah(alam semesta). Dengan mengkaji ayat-ayat qouliyah manusia akan mengenal Tuhannya karena Al-Qur'an menyebutkan tentang Allah secara jelas kalau ada pertanyaan siapakah Allah?Surat Al-Ikhlas yang pendek sudah dengan jelas menjawabnya atau ayat kursi yang menyebutkan 10 sifat-sifat Allah. Dengan memikirkan alam semesta yang terbentang luas, seseorang dapat mengenal adanya Sang Pencipta dan Pengatur alam beserta isinya. Dengan mengenal Allah seseorang telah menemukan sumber kecerdasan spiritual yang sebenarnya.

b. Mengenalkan anak kepada Rasul (ma'rifatur rasul) yaitu dengan mengenalkan sosoknya, peran dan pungsinya, cara mengamalkan Islam melalui 


\section{Peranan Orang Tua dalam Membina Kecerdasan Spiritual Anak dalam Keluarga H. Zulkifli Agus}

petunjuknya, mengetahui, memahami, dan mengamalkan sunnahnya dan menjalankan ibadah dengan baik. Secara alami jiwa manusia, khususnya pada masa balita, mudah terpesona pada sosok yang menarik hatinya sehingga dia cepat mengidolakan, mengagumi, meniru, dan mengikuti jejak langkahnya. Oleh karena itu, orang tua harus mengisi ruang figur dan pengidolaan itu dengan sosok Rasulullah SAW. Karena, Rasulullah SAW adalah tokoh idola dan teladan yang tepat serta mendidik. Secara mutlak beliau adalah manusia paling sempurna dan utama di antara para rasul Allah SWT.(Samihan mahmud Gharib,2006:94). Mengenal Rasul tidak hanya fisik atau atau penampilannya, tetapi segala aspek syar'i berupa sunnah yang diwariskan kepada umatnya berupa tingka laku, perkataan, atau sikap. Mengenal Rasul dapat dilakukan melalui sirah yang menggambarkan kehidupan beliau serta latar belakangnya, seperti nasab. Selain itu mengenal Rasul bisa melalui sunnah dan hasil dakwah beliau yang memberikan gambaran tentang pribadi Rasulullah yang sebenarnya.(Robbbani Pers,2009:125). Dengan mengenal Rasul seseorang akan mendapatkan contoh,teladan yang baik dalam mengembangkan kecerdasan spiritualnya.

c. Mengenalkan anak kepada Islam (ma'rifatul Islam) yaitu dengan mengenalkan bahwa Islam agama yang benar, Islam agama rahmatan lil 'alamin.Mengenal Islam dengan cara mengenali hakikat agama Islam, mengenali ajaran-ajarannya dan misi-misinya. Ketika seseorang mengenali Islam secara sempurna “...ia akan selalu menundukkan wajahnya kepada Allah dan berserah diri kepadaNya, pada saat itulah ia bersih dari kesombongan dan kepongahan. Jika itu yang ia lakukan, ia akan merasakan kedamaian hidup dalam naungan-Nya, terjamin kehidupannya, terbebas dari cemas dan takut." (Jasmin,2009:127). Dengan mengenal Islam seseorang akan menemukan jalan yang harus dilalui dalam menempuh perjalannan menuju kecerdasan spiritual yang sebenarnya.

d. Mengenalkan anak kepada dirinya (ma'rifatul insan) yaitu mengenalkan jati dirinya, siapa dirinya, siapa pencipta dirinya, dan untuk apa dia diciptakan. Setiap manusia, "siapa pun dan apa pun kedudukannya, manusia harus memahami hakikat diri dan kehidupannya. Hal ini penting agar manusia bersikap dan berlaku adil terhadap dirinya, terhadap Penciptanya, terhadap sesama manusia, dan terhadap makhluk-makhluk lain..."(Ibid: 202). Mengenal jati diri dengan mengenali bahwa dirinya diciptakan oleh Allah SWT dalam keadaan sempurna yang dibekali dengan hati, akal, dan jasad yang harus dijaga, dibina, dan diarahkan untuk siap mengemban amanah. "...Amanah itu ibadah dan khilafah..."(Syamsu Yusuf LN:38). Dengan mengenal dirinya seseorang menyadari akan kebutuhannya terhadap kecerdasan spiritual.

e. Mengenalkan anak kepada al-Qur'an (márifatul qur'an) yaitu mengenalkan"...bahwa al-Qur'an adalah sumber petunjuk dalam menuju kemuliaan hidup".(Saad Riyadh,2007:94). "Mengenal al-Qur'an dimulai dari definisinya, kemudian nama-namanya, konsekuensi iman kepadanya, bahaya melupakannya, dan syarat mendapat manfaat darinya".(Jasmin:202). 
Dengan mengenal al-Quran seseorang akan mengetahui dan menemukan pedomanhidup untuk mengembangkan kecerdasan spiritualnya.

\section{Deskripsi Peranan Orang Tua dalam Membina Kecerdasan Spiritual Anak dalam Keluarga}

Keluarga merupakan institusi pendidikan utama dan pertama bagi anak. Karena anak untuk pertama kalinya mengenal pendidikan didalam lingkungan keluarga sebelum mengenal masyarakat yang lebih luas. Disamping itu keluarga dikatakan sebagai peletak pondasi untuk pendidikan selanjutnya. Pendidikan yang diterima anak dalam keluarga inilah yang akan digunakan oleh anak sebagai dasar untuk mengikuti pendidikan selanjutnya disekolah.

Orang tua sebagai pendidik utama bagi anak yang merupakan penanggung jawab penuh terhadap pendidikan anak-anaknya. Tugas dan tanggung jawab orang tua dalam keluarga terhadap pendidikan anak-anaknya lebih bersifat pembentukan watak, agama dan spiritualnya.

Syamsu Yusuf LN, berpendapat orang tua berperan sebagai berikut:

a. Pemberi rasa aman bagi anak dan anggota keluarga lainya.

b. Memenuhi kebutuhan baik fisik maupun psikis,

c. Menjadi Sumber kasih sayang dan penerimaan,

d. Model pola perilaku yang tepat bagi anak untuk belajar menjadi anggota masyarakat yang baik.

e. Pemberi bimbingan bagi pengembangan perilakuyang secara sosial dianggap tepat.

f. Pembentuk anak dalam memecahkan masalah yang dihadapinya dalam rangka menyesuaikan dirinya terhadap kehidupan.

g. Pemberi bimbingan dalam belajar keterampilan motorik, verbal dan sosial yang dibutuhkan untuk penyesuaian diri.

h. Stimulator bagi pengembangan kemampuan anak untuk mencapai prestasi, baik disekolah maupun di masyarakat.

i. Pembimbing dalam mengembangkan aspirasi.

j. Sumber persahabatan atau teman bermain bagi anak sampai cukup usia untuk mendapatkankan teman diluar rumah, atau apabila persahabatan diluar rumah tidak memungkinkan. (Syamsu Yusuf LN, 2001:38).

Sebuah rumah tangga terkadang terdiri dari ayah, ibu ditambah saudara anggota lain; kakek, nenek, dan lain-lain. "Rumah tangga merupakan sebuah lingkungan alamiah, yang mengemban tugas dalam pembinaan anak. Para psikolog, pendidik dan pembina percaya bahwa rumah tangga merupakan lingkungan terbaik dalam upaya membina seorang anak."(M. Baqir Hujjati, 2003:109). Hubungan dan komunikasi anak dengan kedua orang tua merupakan hubungan paling kuat dibanding berbagai bentuk hubungan lain. 


\section{Peranan Orang Tua dalam Membina Kecerdasan Spiritual Anak dalam Keluarga H. Zulkifli Agus}

Pertumbuhan anak dibawah asuhan ayah dan ibu merupakan sebaik-baik sarana bagi pembinaan spiritualnya. Namun demikian, kurangnya pengetahuan anggota keluarga juga dapat berpengaruh negatif bagi keturunan mereka. Kebiasaan dan tradisi yang diperoleh seorang anak dari keluarganya akan diwarnai adat dan kebiasaan teman-temannya. Oleh karena itu Islam melarang bergaul dengan teman yang jahat dan buruk.

Pendidikan keluarga dipandang sebagai pendidikan pertama karena peranannya yang begitu besar sebagai peletak pondasi pengembanganpenembangan berikutnya. Pendidikan yang diberikan orang tua terhadap anak mempunyai peran yang besar sekali bagi kehidupan dan masa depan anak, karena pada dasarnya pendidikan merupakan upaya untuk pribadi insan yang sejati.

Peranan ayah terhadap pendidikan anaknya harus lebih banyak daripada peranan ibu.Al-Qur'an sudah memberi contoh bahwa peran orang tua terhadap anaknya lebih banyak terutama ayah yang terdapat 17 dialog tematik antara orangtua dengan anak dalam al-Qur'an yang tersebar dalam 9 Surat. Adapun rinciannya sebagai berikut; 14 dialog antara ayah dengan anaknya, 2 dialog antara ibu dan anaknya, 1 dialog antara kedua orangtua tanpa nama dengan anak. (http://majalah.hidayatullah.com/2014/10/ayah-dan-kokohnya-jiwa-anak.)

Ayah merupakan sumber pendidikan yang memberikan anaknya tentang manajemen dan kepemimpinan, sebagai penghubung antara keluarga dan masyarakat dengan memberikan pendidikan terhadap anaknya berupa komunikasi terhadap sesamanya memberi perasaan aman dan perlindungan terhadap keluarganya".(Rehani,2001:9).

Luqman Haqani (2004) berpendapat bahwa orang tua memiliki peran sentral dalam pembentukan kecerdasan spiritual anak. Al-Qur'an dan as-Sunnah menjelaskan pentingnya pendidikan keluarga. Peran ayah dan ibu dalam pendidikan keluarga adalah sebagai guru yang wajib membawa anaknya ke jalan Islam.

Keluarga adalah wadah pertama bagi pertumbuhan dan perkembangan anak, jika suasana dalam keluarga itu baik dan menyenangkan maka anak akan tumbuh dengan baik pula. Jika tidak, tentu akan terhambatlah pertumbuhan anak tersebut.

Keluarga memiliki peranan yang sangat penting dalam upaya mengembangkan pribadi anak. Perawatan orang tua yang penuh kasih sayang dan pendidikan tentang nilai-nilai kehidupan beragama dan bermasyarakat, merupakan faktor yang kondusif untuk mempersiapkan anak menjadi pribadi dan anggota masyarakat yang sehat.

Orang tua merupakan orang yang terdekat dengan anak. Di mana sikap dan tingkah laku orang tua akan menjadi panutan bagi anaknya, terutama anak yang masih kecil. Pengalaman anak semasa kecil ini akan terbawa dan membekas sampai ia dewasa. Dan akhirnya akan mewarnai corak kepribadianya. Dalam hal ini orang tua lebih dituntut untuk berperan aktif, karena orang tua merupakan orang yang lebih dekat dengan anaknya. Orang tua yang penuh keseriusan perhatian, penyayang dan tekun menjalankan ajaran-ajaran agama, serta untuk hidup sesuai 
Volume 4 Nomor 2 Edisi Desember 2019

P-ISSN : 2541-3686

nilai-nilai moral yang telah digariskan oleh agama, maka ia dapat membina moral dan mental (pribadi) anaknya secara sehat dan teratur.

Menurut Carl Gustav Jung seorang psikolog terkenal mengatakan, kalau “...orang tua ingin anaknya bertingkah laku baik, terlebih dahulu orang tua harus mengevaluasi dirinya, apakah memang sudah bisa bertingkah laku lebih baik". (http://www. mail- archive.com/balita-anda/balita-anda.com/msg ). Berat sekali memang tugas sebagai orangtua, ada tuntutan untuk selalu bisa menjadi teladan bagi anak karena anak akan selalu belajar tentang dunia ini dengan melihat sikap dari orang terdekatnya terutama orang tua.

Orang tua manapun pasti ingin anaknya bisa bertingkah laku yang baik di depan orang banyak, menghormati orang lebih tua, sadar akan hak dan kewajiban orang lain yang bisa membatasi hak dan kewajibannya sendiri, serta peka terhadap orang lain. Pendek kata anak bisa mengikuti norma dan nilai sosial yang berlaku. Sungguh bukan hal yang mudah untuk diserap dan dipelajari anak, namun orang tua begitu ingin mereka tahu dan bisa mengamalkan hal-hal baik tersebut.

Dengan demikian orang tua mempunyai peranan yang besar, karena baik buruk atau sukses tidaknya anggota keluarga merupakan tanggung jawabnya. Orang tua sebagai kepala keluarga dituntut untuk mewarnai keluarga dengan nilai dan akhlak yang baik, suri tauladan yang baik, menyelamatkan anggota keluarga dari segala bentuk keresahan dan kesusahan, baik susahnya perjuangan dunia maupun akhirat.

Menurut Samihah Mahmud Gharib (2006) peran orang tua dalam membina kecerdasan spiritual anak dalam keluarga, sebagai berikut:

a. Membantu anak untuk merumuskan misi hidupnya kepada sumber kecerdasan spiritual yang sebenarnya yaitu Allah SWT.

b. Mendidik anak dengan mencontohi dan meneladani Rasulullah untuk mewujudkan misi hidupnya.

c. Mengarahkan anak ke jalan yang benar (agama Islam) dalam meniti jalan untuk mencapai misi hidupnya.

d. Mengajarkan dan memahamkan kepada anak pedoman (al-Qur'an) untuk panduan dalam mengejar misi hidupnya.

e. Memotivasi anak untuk berjuang mewujudkan dan mengamalkan misi hidupnya.

Adapun penjelasan tentang peranan orang tua terhadap anaknya sebagai berikut:

Membantu anak untuk merumuskan misi hidupnya kepada sumber kecerdasan spiritual yang sebenarnya yaitu Allah SWT. yaitu orang tua mengenalkan kepada anak bahwa Allah SWT itu ada (Wujud), “...Tuhan yang telah menciptakan dan memelihara alam semesta dengan kekuasaan dan kasih sayangNya..."(Jasmi, 2009:59). Dibuktikan melalui ayat-ayat qouliyah dan kauniyah yang mencakup berbagai dalil-dalil baik dalil fitrah, dalil inderawi, dalil rasional, dalil nash, dan dalil sejarah. 


\section{Peranan Orang Tua dalam Membina Kecerdasan Spiritual Anak dalam Keluarga H. Zulkifli Agus}

Jika anak memahami dengan baik tentangadanya Allah SWT melalui dalil-dalil yang telah disebutkan di atas tentu ia akan menyadari bahwa Allah SWT merupakan sumber spiritual yang sebenarnya yang telah menciptakan dirinya, maka ia akan menjadikan misi hidupnya hanya untuk Allah semata dengan membenarkan, mempercayai, dan mengabdi kepada Allah dan memantapkan keimanan kepada-Nya.

Mendidik anak dengan mencontohi dan meneladani Rasulullah untuk mewujudkan misi hidupnya. Yaitu orang tua mendidik anaknya dengan mengenalkan sosok Rasulullah, yang mencakup kedudukan, sifat-sifat, dan tugastugasnya. "Rasul adalah seorang lelaki yang mempunyai sifat-sifat mulia yang dipilih dan diutus Allah SWT dengan membawa risalah kepada manusia. Rasul adalah manusia terbaik di antara manusia lainnya. Rasul adalah contoh dan teladan dalam aplikasi risalah Islam dalam kehidupan sehari-hari".(Tim Penyusun Modul,2009:115).

Jika anak telah mengenal sosok Rasul dengan baik, tentu dia akan membutuhkan, mencintai, dan meneladani Rasul dalam mengaplikasikan risalah Islam untuk mewujudkan misi hidupnya, dan menetapkan keimanan kepadanya. Mengarahkan anak ke jalan yang benar (agama Islam) dalam meniti jalan untuk mencapai misi hidupnya.

Menurut Jasiman (2009) Yaitu agar orang tua mengajarkan kepada anaknya bahwa Islam agama yang benar, agama yang dibawa oleh Rasulullah yang berasal dari Allah SWT. Islam adalah agama yang sempurna yang menjadi pedoman hidup yang memuat ajaran-ajaran, hukum dan akhlak, perintah dan larangan Allah dan Rasul-Nya.

Jika anak telah mengenal Islam dengan baik dalam dirinya “...akan melahirkan pemikiran dan gagasan-gagasan yang Islami, pada akhirnya akan menghasilkan aktifitas yang Islami"(Jasmin:148). Dengan mengenal Islamdia akan menyadari bahwa Islam adalah jalan yang lurus yang harus ia titi dalam mengarungi kehidupannya untuk mencapai misi hidupnya.

Mengajarkan dan memahamkan kepada anak pedoman (al-Qur'an) untuk panduan dalam mengejar misi hidupnya.Yaitu mengajarkan al-Qur'an kepada anak bahwa "al-Qur'an kalamullah, merupakan mukjizat yang diturunkan ke hati Nabi Muhammad SAW, diriwatkan kepada manusia secara mutawatir, dan membacanya merupakan ibadah".(Ibid:204).

Al-Qur'an memiliki sejumlah nama lain sebagaimana Allah sebutkan dalam alQur'an itu sendiri. Masing-masing nama memberikan gambaran yang jelas mengenai fungsinya bagi kehidupan manusia. Al-Qur'an sebagai kitab yang benar yang harus dibaca dan dihafalkan, sebagai petunjuk bagi manusia, sebagai pembeda antara yang haq dengan yang batil, sebagai rahmat Allah bagi manusia, sebagai cahaya yang menerangi jalan hidup manusia, sebagai obat yang mengobati penyakit yang ada dalam dada manusia, sebagai nasihat yang sangat berguna bagi manusia, dan lain sebagainya. 
P-ISSN : 2541-3686

Jika anak memahami al-Qur'an dengan baik dia akan menyadari begitu pentingnya belajar dan mengajarkan al-Qur'an, dia akan selalu membaca, menghafal, dan mengamalkan al-Qur'an, dia akan menjadikan al-Qur'an sebagai pedoman hidupnya yang akan memandu dalam mengejar misi hidupnya. Memotivasi anak untuk berjuang mewujudkan dan mengaplikasikan misi hidupnya.

Yaitu mendidik dan memotivasi untuk membangun jati diri anak. Anak merupakan titipan Allah yang dibekali dengan potensi hati yang suci, akal yang jerni dan jasad yang sempurna, maka orang tua harus menjaga kesucian hatinya dan mengembangkan kecerdasan hatinya (kecerdasan spiritual) dengan mengenalkan kepada Sang Pemilik hatinya, dimulai “...sejak detik pertama anak menghirup nafas kehidupan di dunia. Maka dari itu Islam menganjurkan dengan berazan pada telinga kanan bayi yang baru lahir dan ikamah di telinga kirinya. Agar suara yang pertama kali mengetuk hati anak adalah kalimat panggilan yang mengagungkan nama Tuhan dan kalimat syahadat yang merupakan kunci awal masuk Islam" (Syamihan Mahumd Gharib, 2006:38). Kemudian memberikan nama yang baik, mengakikahkannya, serta mengajak anak untuk selalu berinteraksi kepada Allah dengan mengkaji ayat-ayat-Nya.

Menjaga kejernihan akalnya dengan mengajak anak untuk berfikir dan bertafakur tentang ciptaan Allah yang menunjukkan tanda-tanda kebesaran dan keagungan-Nya. Menjaga kesempurnaan jasadnya dengan menghindar dan menjauhkan dari hal-hal yang mencelakakan, merugikan, dan membahayakan anak seperti kemaksiatan. Melatih anak untuk memanfaatkan jasad yang sempurna dengan selalu bersyukur kepada Sang Pemilik Jasadnya dengan cara menjalankan semua perintah-Nya dan meninggalkan segala larangan-Nya.

Jika anak telah mengenal jati dirinya dengan baik, maka dia akan memahami hakikat dirinya bahwa dia adalah makhluk ciptaan Allah yang dimuliakan dari pada makhluk lainnya, yang dibebani tugas dan tanggung jawab untuk menjaga kemulian dirinya agar tidak terjatuh ke jurang kenistaan.

Sebagaimana Firman Allah dalam surat At-Tin (95:4).

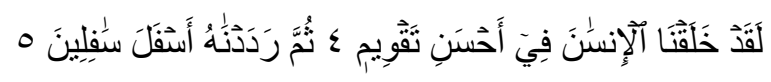

Artinya:,"sesungguhnya Kami telah menciptakan manusia dalam bentuk yang sebaik-baiknya. Kemudian Kami kembalikan dia ke tempat yang serendahrendahnya (neraka)" (Depag RI, 2014: 597).

Dengan memahami ayat di atas maka dia akan menggunakan potensi yang ia milikiuntuk berjuang dan berkorban menghindari dirinya dari jurang kenistaan, berjuang dan berkorban untuk mewujudkan misi hidupnya dan mengaplikasikannya dalam kehidupan dengan pribadi muslim sejati yang memiliki kecerdasan spiritual yang tinggi. Menurut Imam Syahid Hasan Al-Banna bahwa karakter pribadi muslim sejati yaitu memiliki aqidah yang lurus, ibadah yang benar, akhlak yang mulia, jasmani yang kuat, fikiran yang cerdas, berjuang melawan hawa nafsu, pandai menjaga waktu, teratur dalam urusannya, mandiri, bermanfaat bagi 


\section{Peranan Orang Tua dalam Membina Kecerdasan Spiritual Anak dalam Keluarga}

\section{H. Zulkifli Agus}

orang lain. ( http://abatihawa.blogspot.co.id/2008/07/hassan-al-banna-dan-ikhwanulmuslimin.)

Dari berbagai penjelasan di atas, penulis menyimpulkan bahwa peranan orang tua dalam membina kecerdasan spiritual anak adalah mendidik, mengasuh, menjaga, membantu dan mengembangkan kecerdasan spiritual anak untuk mengantarkannya kepada sumber kecerdasan spiritual yang sebenarnya (Allah SWT) melalui ajaran Islam yang tertuang dalam al-Qur'an dan Hadits yang telah dicontohkan oleh Rasulullah.

\section{Simpulan}

Setelah diadakannya penelitian dengan metode library research tentang peranan orang tua dalam membina kecerdasan spiritual anak dalam keluarga, maka dapat penulis simpulkan sebagai berikut:

1. Kecerdasan spiritual (SQ) adalah kecerdasan jiwa manusia yang berasal dari fitrah manusia itu sendiri yang berkaitan erat dengan aspek religious dan ketauhidan yang dapat membantu seseorang membangun jatidirinya menjadi pribadi insane sejati, kreatif ketika dia dihadapkan pada masalah kehidupan, dan mampu menyelesaikannya dengan baik dengan memperoleh kepuasan, ketenangan dan kedamaian hati, serta mampu memaknai setiap kegiatannya sebagai ibadah dalam pengabdian kepada Allah SWT. Dan ini merupakan kecerdasan terpenting dalam menapaki kehidupan di dunia ini demi mencapai misi hidup kesuksesan di dunia dan akhirat.

2. Urgensi pembinaan kecerdasan spiritual padaanak, karena dengan kecerdasan spiritual itu membuat anak mampu memfungsikan IQ dan EQ secara efektif dan mampu berfikir lebih jernih, lebih positif untuk menjadi orang yang lebih baik sehingga mampu menjadi pribadi muslimsejati 
RAUDHAH Proud To Be Professionals gurnal Tarbiyakndlamiyak

Volume 4 Nomor 2 Edisi Desember 2019

P-ISSN : 2541-3686

\section{DAFTAR PUSTAKA}

Ahmad Syafii Maarif, Pendidikan Islam dan Proses Pemberdayaan Umat, Jurnal Pendidikan Islam

Aravik, Havis, 2018. Pengantar Studi Islam, Palembang: Rafah Press.

Ary Ginanjar Agustian, Rahasia Sukses Membangun Kecerdasan Emosi dan Spritual ESQ, Jakarta : Agra Wijaya Persada, 2001

Danah Zohar dan Ian Marshal,.SQ: Memanfaatkan Kecerdasan Spritual dalam Berfikir Integralistik dan Holistik untuk Memaknai Kehidupan. Bandung: Mizan, 2001

Departemen Agama RI, Al-Qur'an dan Teremahannya, Bandung: CV Penerbit Diponegoro, 2014

Hasan Langgulung, Manusia dan Pendidikan Suatu Analisa Psikologi dan Pendidikan, Jakarta : PT. Al Husna Zikra, 1995

hikmah Press,2001

http://abatihawa.blogspot.co.id/2008/07/hassan-al-banna-dan-ikhwanulmuslimin.(diaklses Nopember 2019)

http://buleksiet.blogspot.co.id/2013/06/keterkaitan-kecerdasan-emosi-dan (diakses September 2019)

http://majalah.hidayatullah.com/2014/10/ayah-dan-kokohnya-jiwa-anak. (diakses

Oktober 2019)

http://www. mail- archive.com/balita-anda/balita-anda.com/msg (Diakses

Nopember 2019)

http://www.sarjanaku.com/2013/04/pengertian-lingkungan-sekolah-faktor. (diakses

bulan September 2019)

http://www.scribd.com/doc/6719346/Skripsi-Membina-Kecerdasan-Spritual-Anak

(diakses bukan agustus 2019)

https://zuhdifirdaus.wordpress.com/2008/08/28/etika-pendidikan-pembentukan-

kecerdasan- spiritual.(Diakses Oktober 2019)

Jasiman, Syarah Rasmul Bayan Tarbiyah, Surakarta: Aulia Press, 2009

M. Bagir Hujjati, Pendidikan Anak dalam Kandungan, Bogor : Cahaya, 2003

Rehani, Keluarga Sebagai Institusi Pendidikan dalam Perspektif Al-Qur'an, Baitul

Sa'ad Riyadh, Kiat Praktis Mengajarkan Al-Qur'an Pada Anak, Surakarta: Ziyad

Samihah Mahmud Gharib, Membekali Anak Dengan Akidah, Jakarta: Maghfirah Pustaka, 2006 


\section{Peranan Orang Tua dalam Membina Kecerdasan Spiritual Anak dalam Keluarga}

\section{H. Zulkifli Agus}

Stephen R. Covey, Melampaui Efektifitas, Menggapai Keagungan, Jakarta: PT Gramedia pustaka utama. 2005

Suharsono, Mencerdaskan Anak, Jakarta : Intiusi Press,2000

Sukidi. RahasiaSuksesHidupBahagia, Mengapa SQ LebihPentingdaripada IQ dan EQ. Jakarta: Gramedia, 2004

Syamsu Yusuf LN, Psikologi Perkembangan Anak dan Remaja, Bandung:Rosda Karya, 2001

Syamsu Yusuf LN, Psikologi Perkembangan Anak dan Remaja, Bandung:Rosda Karya, 2001

Tim Penyusun Modul, Modul Tarbiyah Islamiyah, Jakarta: Robbani Press, 2009 Visi Media, 2007

Toni Buzan, Kekuatan ESQ: 10 Langkah Meningkatkan Kecerdasan Emosional Spiritual, terjemahan Ana Budi Kuswandani, Jakarta: PT Pustaka Delapratosa, 2003 